\title{
Energy Engineering Students on Their Way to Expertise in Sustainable Energy
}

\author{
Helena Malkki ${ }^{1}$, Kari Alanne ${ }^{2},{ }^{1,2}$ Aalto University, Laura Hirsto, University of Helsinki
}

\begin{abstract}
Energy engineering is facing new challenges in educating experts in sustainable energy. The aim of this paper is to characterise expertise related to sustainability in higher education. Future challenges and required skills are explored through recent studies, which have listed key competencies that engineers need in their working life. Sustainability and expertise are discussed on the basis of literature and energy curricula are explored on universities' internet pages.
\end{abstract}

Keywords - energy engineering, expertise, curriculum, competencies, life cycle assessment, sustainable energy

\section{INTRODUCTION}

Sustainable energy solutions are important for all sectors of industry and human life for many local and global reasons. The main global challenge is to tackle climate change, greenhouse gas emissions and their post Kyoto targets beyond 2012. It is generally agreed that fossil fuels cause global warming [1] and [2]. Increasing awareness pushes energy producers as well as users to choose more sustainable energy alternatives and to save non-renewable energy resources. Global demand for green solutions and the economy are creating opportunities for new technologies, investment and jobs. New skills required for green jobs also mean new requirements for the education in adopting new technologies, meeting new environmental regulations and shifting towards renewable sources of energy. [3]

Energy expertise is essential when making decisions about future energy choices, for example. These choices have consequences on the whole society where energy is used. Even though both energy and environment are closely linked to each other in politics and strategies, increasing environmental awareness and systems thinking still present challenges for teaching energy engineering. This was also identified in the Aalto University Teaching and Evaluation report published in 2011 [4]. The report has presented the same development needs as other national and international analyses of research and higher education in Europe and Finland. The main challenges are increasing internationality, career systems, research infrastructure and academic leadership [4]. These challenges should be observed in research based university education. This development of higher education and research is as an important part of public responsibility in the Bologna Process [5]. Expertise is called employability in the Bologna process and a definition is agreed on this term: "A set of achievements - skills, understandings and personal attributes - that make graduates more likely to gain employment and be successful in their chosen occupations, which benefits themselves, the workforce, the community and the economy."

A university should educate high-level professionals to work as energy and environment experts and to make research- and knowledge-based decisions. In this sense, university education should help students in developing their expertise to be able to make the best decisions at work after their graduation, taking into account both energy related and environmental viewpoints. Sustainable use of energy, natural resources and human living environment are key focus areas set out in Aalto University's strategy. These issues have been pointed out to be the main objectives in contributing to sustainable development. Actions to enforce the plan of sustainable development are already under way [6].

In this study, the role and demands of know-how in sustainable energy engineering are investigated through recent Finnish studies [7], [8] and [9], which have listed key competencies that engineers need in working life. Finnish technical universities are aware that sustainability must be incorporated into the energy engineering curriculum in order for the future graduates to acquire these competencies and cross-curricular needs. However, this remains to be implemented in the energy degree programmes. This kind of situation seems to be true also in other universities outside of Finland. Batterman et al [10] have reviewed more than two dozen energy-related programmes in U.S. and European universities and they identified no comprehensive set of educational competencies in the area of energy and sustainability. A current situation of sustainability and energy degree programmes will be mapped in a follow-up study to European universities. This paper discusses teachings in sustainable energy engineering and focuses on elements which are useful for students on their way towards sustainable energy expertise.

\section{DEVELOPMENT OF EXPERTISE}

Expertise can be developed in formal and informal settings [11]. Education provides basic skills to people who are able to function independently, perceptively and effectively, allowing them to excel in their field of work [12]. Developing the skills of students is an important goal for teaching and preparing students for professional life. However, developing skills is not enough. Barnett \& Coate (2005) [13] suggest that there are three dimensions to developing curriculum in higher education, that is, knowing, acting and being, all of which should be considered. This refers to the fact that in formal higher education, learning of new knowledge is usually well 
represented, and the development of certain skills is also considered. However, the dimension of being is often not that well integrated into the curricula."Being" refers to the view growing up to be, for example, an energy expert. Nevertheless, teaching approaches should include the investigation of societal and working life challenges in open interaction with stakeholders like industry and employers. Expertise also requires mastering the working environment and the tools. Students could enhance their skills by putting them into practice during their education. Expertise does not end with graduation from higher education institutes, universities and polytechnics, but it continues throughout the whole working career.

Developing perspectives is of great value for an expert and it might take a number of years before a person is considered to be a real expert [14]. Klein and Hoffman have emphasised that continuous challenges are more relevant than the time spent on the job to develop expertise. They have stated that different domains have different requirements for expertise, but they all have common skills, which are observation of performance, assessment, modelling, relieving anxiety and developing a professional identity. There is also a progression of five levels of expertise, ranging from the beginner to the master and they are novice, advanced beginner, competent, proficient and expert. "Novices see only what is there and experts see what is not there" describes the difference between the lowest and highest level of expertise [14].

The Oivallus final report which was initiated by Finnish working life stakeholders has listed the teacher directed and learner cantered practices presented in Table 1 [8]. According to them, the goal of education should be a better balance between the different ways of learning. Future teaching methods do not mean that the old ones must be totally replaced with the new ones, but they could involve simple improvements and new arrangements. For instance the chairs and tables should be movable in the learning room so that the learners could see each other. The report has also recommended that learning practices could closely match the reality of the working environment.

TABLE I

VARIOUS TEACHING AND LEARNING PRACTICES [8].

\begin{tabular}{|l|l|}
\hline Teacher directed & Learner cantered \\
\hline direct instruction & interactive exchange \\
\hline knowledge & skills \\
\hline facts and principles & questions and problems \\
\hline theory & practice \\
\hline curriculum & projects \\
\hline one size fits all & personalized \\
\hline competitive & collaborative \\
\hline classroom & global community \\
\hline summative tests & formative evaluations \\
\hline
\end{tabular}

In the future, experts will be working in networks, through which the members will interact and provide interdisciplinary solutions to problems. The political road map for the European Higher Education Area in 2012-2015 focuses on three main goals in the face of the economic crisis: to provide higher quality education to more students, to equip students with better employable skills, and to increase student mobility [15]. Expertise should be based on broad multidisciplinary and interdisciplinary competences from the perspectives of working life [7]. This kind of working is necessary to adapt to the shift from an industrial society towards an information and experiential society [8]. Expertise in all sectors of higher education is at the moment commonly based on knowledgedriven research and relevant practices and their evaluation. This knowledge-driven education gives the student the basic skills to understand research knowledge and also to produce new knowledge in his own field according to approved procedures. However, expertise is not the only quality of individuals since expert knowledge should be learned and shared with others in an interactive community.

\section{SUSTAINABLE ENERGY IN EDUCATION}

Sustainability is one of the main objectives in the Europe's energy policy [16]. The above paper highlights a strategy for sustainable, competitive and secure energy where sustainability is connected to renewable and other low carbon energy sources and carriers. Also carbon free nuclear energy and clean coal technologies can be sustainable energy. The definition of energy from renewable sources includes wind, solar, aerothermal, geothermal, hydrothermal and ocean energy, hydropower, biomass, landfill gas, sewage treatment plant gas and biogases in the European Union Directive on the promotion of the use of energy from renewable sources [17]. This definition excludes energy from fossil sources. This directive introduces also the sustainability criteria for biofuels. These energy issues are crucial in sustainable energy education.

Sustainability includes a challenging combination of economic, ecological and social dimensions and needs interdisciplinary co-operation in education [18] and [19]. The teachers have to plan in cooperation with the other teachers, how they could put sustainability aspects into context within the curriculum and their courses. In universities the goal of teaching should be the students' education, which promotes expertise in tackling global ecological challenges.

Expertise in sustainable development means understanding the relationships and conflicts between the various actors' parties and technical solutions. The holistic view of the energy systems, the deep know-how on energy engineering and the ability of critical and creative thinking are basic skills for promoting sustainable energy. The sustainable solutions should be based on long-term goals of ecological, socioeconomic, energy and material efficiencies. Decision making for sustainable solutions might take more time than expected when changes of mindset are needed. Table 2 presents the 
current state of sustainable development in higher education of technology [20].

TABLE 2

CURRENT STATE OF SUSTAINABLE DEVELOPMENT IN HIGHER EDUCATION OF TECHNOLOGY [20].

\begin{tabular}{|l|l|}
\hline $\begin{array}{l}\text { Views of sustainable } \\
\text { development }\end{array}$ & Current state \\
\hline Strengths & $\begin{array}{l}\text { many individual solutions, } \\
\text { many enthusiastic teachers and researchers }\end{array}$ \\
\hline Weaknesses & $\begin{array}{l}\text { no uniform view, } \\
\text { different technology actors, } \\
\text { low visibility }\end{array}$ \\
\hline Opportunities & $\begin{array}{l}\text { a good basis for the systemic and life-cycle } \\
\text { based development, } \\
\text { strong problem solving skills }\end{array}$ \\
\hline Challenges/ Threats & $\begin{array}{l}\text { taken for granted, } \\
\text { system-level solutions }\end{array}$ \\
\hline
\end{tabular}

In the coming decades, renewable energy sources will not be able to satisfy the total demand for energy [1]. Environmental degradation and especially climate change is also challenging the education of energy engineers.

\section{FUTURE TRENDS IN ENERGY ISSUES}

When educating future energy engineers it is important to consider the future trends in energy issues in different industrial sectors. Following future trends in energy issues are mostly based on the FinnSight 2015 report [7]. This report's main conclusion is that research and innovation activities have to be strengthened in the areas of energy systems, entire production-consumption chains and energy and material efficiencies. There is growing interest to focus on the security of energy supplies and on renewable and clean energies. Efforts in these fields could combat climate change and scarcity of raw materials. Policy innovations and voluntary agreements could also improve the use of sustainable energy and awareness in environmental impacts. Environmental awareness grew during 1980 - 1990, but the climate change became widely recognized first in the beginning of the $21 \mathrm{st}$ century [9]. Recognized climate impacts are mainly mitigated through various attempts to decrease the emissions of greenhouse gases by reducing the use of fossil fuels. These efforts promote the global transition to renewable fuels. Emission trading introduced by the EU increases the cost of using fossil fuels which is also a driver for new decentralized power generation technologies. Moreover, energy and material efficiency have potential for improvement throughout the society. Sustainable energy solutions are also relevant for instance in the waste management and transport sector. [7]

The forest industry is also facing global changes. The change will focus on renewable raw materials and the shift from the paper and cellulose industry to special chemicals and technologies. The use of wood in energy production will bring the actors of energy and forest industries together. Nuclear energy technology will gain ground because of its carbon dioxide emission free heat generation process. Fuel cells and solar energy face high expectations, but advances are needed in material and manufacturing technologies. Renewable energy production methods are nevertheless evolving rapidly. Driving forces are needed for sustainable development, security of supply, political agreements and emerging markets. New solutions must be developed in the field of decentralized energy systems including the entire supply and demand chain starting from production to energy use. The FinnSight 2015 report has emphasized the need for strong cooperation between the different technology developers. [7]

These future trends also require continuous adjustments to be made to the energy engineering programmes. Higher education should educate energy engineers in different industrial sectors so that they are able to act and make the correct sustainable choices in tomorrow's environment. In Barnett's \& Coate's terms [13], these engineers ideally see themselves as part of the whole society, and build their identity as engineers with respect to sustainability in whatever they do.

\section{FUTURE EXPERTISE IN `ENVIRONMENT AND ENERGY}

Today, students and engineers are facing increasingly complex tasks in energy issues. Energy engineering education normally prepares students to develop technical competences in the energy sector. However, policies and the society are emphasizing life cycle thinking and system approach in preparing long-term energy decisions. The new items integrated in energy engineering education should involve sustainability aspects of energy systems. An energy engineer requires analytical methods and tools to implement the concepts and best design practices in sustainable energy systems. The life cycle based approaches incorporated in energy engineering education would provide the ideal skill set for tackling a wide range of energy problems. Life cycle assessment (LCA) has become a core element in environmental policy and a critical analysis tool to provide broad perspectives needed to address complex problems of systems [21] and [22]. LCA is based on internationally agreed environmental management standards ISO 14040 [23] and ISO 14044 [24]. According to these ISO standards, LCA can be used in many applications of society to assess environmental aspects and potential environmental impacts in different phases of product systems. These outcomes are useful in seeking for balanced sustainable solutions to optimize use of natural resources and environmental consequences along an energy product's life cycle.

Skills of life cycle thinking and systems approach are necessary in preparing long-term energy decisions. In the coming decades, renewable energy sources will not be able to satisfy the total demand for energy [25] and [1]. The Finnish book Energy Visions 2030 for Finland states that there are still negative environmental impacts although all energy would be produced using renewable and sustainable energy sources especially in the case when energy consumption increases continuously. The book gives examples:

- wide utilisation of biomass as an energy source requires the use of large land areas, and effective cultivation may cause serious changes in the soil nutrient cycle 
- renewable energy technologies also require nonrenewable material inputs [1].

The FinnSight 2015 project [7] has studied the future needs of competencies in science, technology, society, business and industry. The Environment and Energy panel have brought up the ten important areas of expertise [7]:

- ecosystems,

- environmental management in Finland and globally,

- urban environments,

- water systems and water purification systems,

- biomass as an energy resource and their production systems,

- more efficient use of energy, negawatts,

- new energy production systems and their integrations,

- new technologies: production and use,

- logistics, distribution and

- mobile and distributed technologies as a platform for energy and environmental services.

Future expertise on environmental management of energy engineering should involve awareness of global problems in mapping and foresight of the environmental risks. Life cycle and systems thinking would increase environmental awareness in screening the systems. Future skills in energy education should also include the set of different sustainability tools [26] and [27].

\section{CONCLUSIONS AND DISCUSSION}

Energy engineers need expertise to solve global and local environmental problems. They need a holistic view on energy systems, a deep know-how of energy engineering and the ability to think critically and creatively to sustainably solve these problems. Regarding future trends in energy issues, sustainable solutions should be based on long-term goals for the ecology, the economy and for energy and material efficiencies. It is also important to address other environmental risks and impacts than global warming when considering energy solutions in education. The environmental impacts should be calculated through whole energy production chain from raw material acquisition to the end use of waste. Expertise in sustainable energy faces complex environmental, economical and societal issues and the advancement in expertise requires competencies to understand and manage different tools and various cognitive perspectives when seeking for the sustainable solutions.

A better balance is needed between various teaching and learning practices in addition to the skills and educational learning outcomes in building the students' future careers. However, it seems that developing teaching practices is not enough. Future education should support identity development and collaboration by working in groups instead of working alone. Also, it could be helpful if the structures of education would support collaborative teaching and life cycle thinking integration in all energy engineering issues. In addition to formal education, the use of more informal learning environments, such as workplace-learning could motivate students to acquire deeper understanding of the role of sustainability in energy engineering and to learn how to use life cycle approaches in authentic environments. Integrating various learning environments would help the students to enhance their sustainable energy expertise and possibly develop multidisciplinary and interdisciplinary skills for sustainable energy solutions throughout their education. After having graduated, expertise should continuously be developed throughout the entire working career. The integration level of energy and sustainability still seems to be low in the curriculum. This research will continue by investigating practices and a current situation of sustainability in energy related degree programmes in Finnish and European universities.

\section{REFERENCES}

1. Energy Visions 2030 for Finland. Publisher: VTT and Edita Publishing, 2003, 3rd edition. ISBN 951-37-3596-6.

2. Energy Use - Visions and Technology Opportunities for Finland. Publisher: VTT and Edita Publishing, 2007. ISBN 978-951-37-47412-8.

3. Strietska-Ilina, O., Hofmann, C., Haro, M. D., et.al. Skills for Green Jobs: A Global View. Synthesis Report based on 21 Country Studies. ILO Publications, October 2011. ISBN 978-92-2-125091-3.

4. Learning together - towards enhancing the co-creation of education. Teaching and Education Evaluation (TEE) 2010 - 2011. Levander, L. \& Koivisto, R. (Eds.), Publisher Aalto University, Project Report, 2011. ISBN 978-952-60-4266-4. [Accessed 12.3.2012] Available: www.aalto.fi/en/

5. From Berlin to Bergen. Executive Summary of the General Report of the Bologna Follow-up Group to the Conference of Ministers Responsible for Higher Education, Bergen, 19 - 20 May 2005. [Accessed 18.5.2012]. Available: http://www.bolognabergen2005.no/Bergen/050503_General_rep.pdf

6. Strategic Development of Aalto University. Aalto University's strategy. 2012. Edition Jan 2012. [Accessed 12.3.2012] Available: www.aalto.fi/en/

7. FinnSight 2015. The Outlook for Science Technology and Society. Finnish Academy and Tekes - the Finnish Funding Agency for Technology and Innovation. Libris Oy, 2006. ISBN 951-715-610-3 \& ISBN 951-715-611-1. Available: www.finnsight2015.fi

8. Competence Needs of Learning. Oivallus, Final report, 2011. The Confederation of Finnish Industries EK. Available: http://ek.multiedition.fi/oivallus/fi/

9. Korhonen-Yrjänheikki, K. Future of the Finnish Engineering Education - A Collaborative Stakeholder Approach. Publisher Academic Engineers and Architects in Finland - TEK, 2011, 317 p. (234+83). ISBN 978-952-5633-48-1. Available: http://lib.tkk.fi/Diss/2011/isbn9789525633498/

10. Batterman, S. A. B., Martins, A. G., Antunes, C. H., et. al. Development and Application of Competencies for Graduate Programs in Energy and Sustainability. Journal of Professional Issues in Engineering Education \& Practice, ASCE, October 2011, p. 198 - 207.

11. Malcolm, J., Hodkinson, P. and Colley, H. The interrelationships between informal and formal learning. Journal of Workplace Learning, 2003 , vol. $15,7 / 8$, p. $313-318$

12. Saukkonen, Sakari. Asiantuntijuuteen kasvaminen korkeakoulutuksessa [To allow for one to excel as an expert in higher education]. In: Vie osaaminen kartalle [Mapping competencies]. Venäjän ja itäisen Euroopan alueasiantuntijuutta etsimässä [Looking for Russian and Eastern European expertise], (in Finnish), Virtasalo, I., Järvinen, J., Rautuma, S., et.al. (eds.), Ovet-hanke, ESR-Project, 2012, p. 13 -24. Available: www.ovethanke.fi

13. Barnett, R. and Coate, K. Engaging the curriculum in higher education. 2005, Maidenhead, UK: Society for Research into Higher Education \& Open University Press. 
14. Klein, G. A., \& Hoffman, R. R. Seeing the invisible: Perceptualcognitive aspects of expertise. In M. Rabinowitz (Ed.), Cognitive science foundations of instruction, p. 203 - 226. Mahwah, NJ: Erlbaum, 1992.

15. Ministers set out path for European higher education in the coming years. EHEA Ministerial Conference in Bucharest 2012. [Accessed 19.5.2012].

Available: http://www.ehea.info/Uploads/\%281\%29/Bucharest\%20Communique\% 202012.pdf

16. Commission of the European Communities 2006. Green Paper. A European Strategy for Sustainable, Competitive and Secure Energy, \{SEC(2006) 317\}, COM(2006) 105 final, Brussels 8.3.2006.

17. Directive 2009/28/EC of the European Parliament and of the Council of 23 April 2009 on the promotion of the use of energy from renewable sources and amending and subsequently repealing Directives 2001/77/EC and 2003/30/EC. Official Journal of the European Union, 5.6.2009.

18. Pope, Jenny et.al. 2004. Conceptualising sustainability assessment. Environmental Impact Assessment, No. 24, 2004, p. 595 - 616.

19. Allenby, B. R., Allen, D. T. and Davidson, C. I. Teaching Sustainable Engineering. Journal of Industrial Ecology, 2007. Volume 11, Number 1, p. $8-10$

20. Takala, A. Tekniikan korkeakoulutus, Ihmisten ja ympäristön hyväksi [Higher education, People and the environment]. Tutkimus kestävästä kehityksestä tekniikan korkeakoulutuksessa [Study on sustainable development in engineering education], (in Finnish). Tekniikan yhteistyöryhmä, Academic Engineers and Architects in Finland - TEK, 2009 , p.142.

21. Guinée, J. B., Heijungs, R., Huppes, G., et.al. Life Cycle Assessment: Past, Present and Future. Environmental Science \& Technology, vol. 45, No. 1, 2011, p. $90-96$.

22. Mihelcic, J. R., Crittenden, J. C., Small, M. J., et.al. Sustainability Science and Engineering: The Emergence of a New Metadiscipline. Environmental Science Technology, 2003, 37 (23), p. 5314-5324.

23. ISO 14040 International Standard. Environmental management - Life cycle assessment - Principles and Framework. International Organization for Standardization. Geneva, Switzerland, 2006.

24. ISO 14044 International Standard. Environmental management - Life cycle assessment - Requirements and guidelines. International Organization for Standardization. Geneva, Switzerland, 2006.

25. Voorspools, Kris. Sustainability of the future; rethinking the fundamentals of energy research. Renewable \& Sustainable Energy Reviews 8 (2004), p. $599-608$.

26. Rorarius, J. Existing Assessment Tools and Indicators: Building up Sustainability Assessment (Some Perspectives and Future Applications for Finland). Finland's Ministry of the Environment (24.08.2007). Available: http://www.ymparisto.fi/download.asp? contentid $=73204$

27. Zamagni, A., Buttol, P., Buonamici, R. et.al. Blue Paper on Life Cycle Sustainability Analysis. Deliverable 20 of the CALCAS project, 2009. Available: http://www.estis.net/sites/calcas/

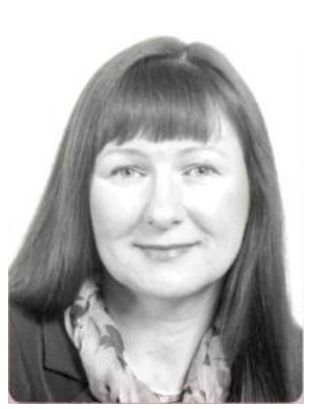

Helena Mälkki graduated with an MSc (Tech.) degree in Energy Technology in 1981 and with a Lic. (Tech.) in 2000 in Energy and Environment at Lappeenranta University of Technology. Since 2010 Helena Mälkki has been working as a Teaching Researcher at Aalto University. Previously, she worked as an Educational Manager at Helsinki University of Technology and as a Senior Research Scientist at VTT (Technical Research Centre of Finland). She has been working also at Elcoteq Network Corporate, Rintekno Consulting Ltd and Helsinki Energy Board.

Mälkki, H., Karevaara, S., Peltonen, P. 2010. EcoMill as a platform for problem based learning in environmentally oriented product design. International conference EESD10 on Engineering Education in Sustainable Development, Gothenburg, Sweden, September 19-22, 2010. 9 p.

Pajunen, M. and Mälkki, H. Legal, sustainable and economical way to control Industrial by-products. A full paper and presentation at the 8th International Conference on EcoBalance Dec. 10.-12., 2008, Tokyo, Japan.
Mälkki, Helena; Virtanen, Yrjö. 2003. Selected emissions and efficiencies of energy systems based on logging and sawmill residues Biomass \& Bioenergy, vol. 24 (2003), p. 321 - 327.

Address: Rakentajanaukio 4, FI-02150, Espoo, Finland

Phone: +358-40-8248748

E-mail: helena.malkki@aalto.fi

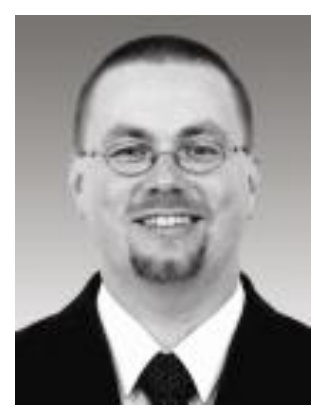

Kari Alanne graduated with an MSc (Tech.) degree in energy economics in 1997. Later, he carried on post-graduate studies in heat transfer and fluid mechanics, HVAC technologies, and system analysis. He obtained the degree of D.Sc. (Tech.) at Helsinki University of Technology in 2007. He has investigated the application of decision analysis in the selection of energy solutions for buildings, focusing on the integration of micro-cogeneration technologies

Since 2006 Kari Alanne has been working as a University Lecturer at the Department of Energy Technology of Aalto University. Previously, he worked as a Research Scientist at VTT (Technical Research Centre of Finland) and as a Special Lecturer and Assistant at Lappeenranta University of Technology. Between 2003 and 2010, Kari Alanne has worked in various overseas institutions including Ruhr-Universität Bochum (Germany), the University of Victoria (Canada), Carleton University (Canada) and De Montfort University (UK).

Alanne Kari and Saari Arto. Sustainable Small-scale CHP Technologies for Buildings: The Basis for Multi-perspective Decision-making. Renewable \& Sustainable Energy Reviews 2004(8) p. 401-431.

Alanne Kari and Saari Arto. Distributed energy generation and sustainable development. Renewable \& Sustainable Energy Reviews 2006 (10) p. 539558.

Alanne Kari, Salo Ahti, Saari Arto and Gustafsson Stig-Inge. Multicriteria evaluation of residential energy supply systems. Energy and Buildings 2007 (39) p. 1218-1226.

Address: Otakaari 4, 02150, Espoo, Finland

Phone: +358-9-470 23591

E-mail: kari.alanne@aalto.fi

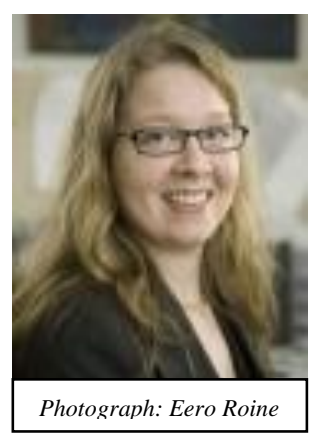

Laura Hirsto has a Ph.D. in the area of educational psychology (2001).She is a Senior Lecturer in University Pedagogy at the University of Helsinki (Finland) (2003-->). The year 2011, she worked as an Educational Developer at the Aalto-University (Finland), leading for example educational development processes and training university teachers in pedagogical thinking and skills.

Hirsto, L \& Tirri, K. (2009). Motivational approaches to the study of theology in relation to spirituality. Journal of Empirical Theology 22 (1), p. 88-102.

Litmanen, T, Hirsto, L. \& Lonka, K. (2010). Personal goals and academic achievement among theology students. Studies in Higher Education 35 (2), p. 195 - 208.

Parpala, A., Lindblom-Ylänne, S., Komulainen, E., Litmanen, T. \& Hirsto, L. (2010) Students' approaches to learning and their experiences of the teaching-learning environment in different disciplines. British Journal of Educational Psychology 80, p. 269-282.

Laura Hirsto has been and is interested in researching learning and motivational processes of higher education students and issues of researchbased educational development in higher education context. She is a member of for example European Association of Research on Learning and Instruction (EARLI).

Address: P.O Box 4 (Vuorikatu 4), 00014 University of Helsinki.

Phone: +358-40-5707793

E-mail: laura.hirsto@helsinki.fi 